\title{
Mental test implementation in the National Technical School in the period between 1942 and 1959: An analysis from the questioning of the notions of center and periphery*
}

\author{
La implementación de pruebas mentales en la Escuela Técnica \\ Nacional en el período entre 1942 y 1959: Un análisis desde \\ el cuestionamiento de las nociones de centro y periferia
}

Recibido: diciembre 3 de 2013 | Revisado: febrero 14 de 2014 | Aceptado: julio 17 de 2014

\author{
AleXandre de CARvalho CASTRO ** \\ Centro Federal de Educação Tecnológica Celso Suckow
}

da Fonseca, Brasil

doi:10.11144/Javeriana.upsy13-5.mtin

Para citar este artículo: Castro, A. de C. (2014). Mental test implementation in the National Technical School in the period between 1942 and 1959: An analysis from the questioning of the notions of center and periphery. Universitas Psychologica, 13(5), 1729-1738. http://dx.doi.org/10.11144/Javeriana.upsy13-5.mtin

Historical Article. This study was supported by grants from the Conselho Nacional de Desenvolvimento Científico e Tecnológico (CNPq)

** Centro Federal de Educação Tecnológica Celso Suckow da Fonseca, Rio de Janeiro, Brasil. Professor of postgraduate programs in human factors. Email:o.aken@uol.com.br
A B S T R A C T :

The aim of this article is to analyze, under the reference of critical studies on transfer of knowledge between center and periphery, how the mental test was implemented in Brazil and came to be used in the students selection process of the Escola Técnica Nacional between 1942 and 1959. The methodology used set up an exploratory-descriptive study in the form of document analysis and has revealed that more than a strictly scientific procedure, the test served to give an appearance of scientific and modernity to the government projects.

Keywords:

centre-periphery; history of psychology; indigenization of psychology; industrial education; mental test

\section{RES UMEN :}

El objetivo de este artículo es analizar, bajo la referencia de los estudios críticos sobre la transferencia de conocimientos entre el centro y la periferia, cómo se llevó a cabo la implementación del test mental en Brasil y llegó a ser usado en el proceso de selección de los estudiantes de la Escuela Técnica Nacional en el período comprendido entre 1942 y 1959. La metodología empleada estableció un estudio exploratorio-descriptivo, en forma de análisis de documentos y han revelado que más allá de ser un procedimiento estrictamente científico, la prueba sirvió para dar una apariencia de modernidad científica y los proyectos del gobierno.

Palabras clave:

centro-periferia; historia de la psicología; indigenización de la psicología; educación industrial; pruebas mentales 


\section{Mental test implementation in the National Technical School in the period between 1942 and 1959: An analysis from the questioning of the notions of center and periphery}

Studies in the history of psychology tend to show that the psychological knowledge considered scientific, from the nineteenth century, was developed mainly in Europe and in the United States, and only after some time it has expanded to other places. Indeed, throughout the twentieth century, psychology has established itself in many countries and regions by the formation of university departments, recognition of professional practice, mass production of books and consolidation of research lines.

Nevertheless, beyond these institutionalization processes, the expansion of psychological knowledge also implied strong influence on the type of society that was being forged, through the design of the social environment as something to be standardized, regulated, and controlled (Rose, 2008). Thus, concepts, studies and theories were constructed in order to streamline, manage and operationalize psychological mediations in various social organizations, especially at schools and industries. Such developments, however, were not seamlessly instead they led to changes and altercations.

This research does not consider as a premise the fact that psychological ideas and practices went through a mere process of unidirectional transmission of regions, considered central to peripheral countries. Especially because this kind of historiographical approach, which indicates strict transmission from the center to the periphery, has a very limited analytical ability, since - if that were the case - the objective of the research is to understand how the peripherals have adapted to the demands of the imported psychological knowledge. Thus, the deterministic prospects and static connotations about scientific knowledge transposition from one region to another (based on a rigid notion of "center" and "periphery") should be questioned (Gavroglu et al., 2008). Mainly because what has been observed in the history of psychology is that the one who receives certain knowledge or import- ed a psychological technique operates the active mode, possibly disagreeing, repelling or adapting implemented theories, due to local customs and behaviors. This finding, which will be further developed in the methodological aspect, must involve a change from the standpoint of historical analysis, i.e. a change of focus from "what" was transmitted to a new look on "how" the knowledge received has been appropriated.

The analysis of this psychological knowledge reception process in countries seen as peripheral has been the subject of interesting research (Adair, 1999). In this sense, it is worth emphasizing that particular approach - indigenization of psychology — began to develop from the 1980s, in studies on the dissemination of psychological knowledge in various places and cultures. Such researches adequately illustrated the active role of receivers of psi knowledge, as they sought to find that these psychology propagation and transplantation, nevertheless, were intended to solve social problems and promote understanding of human thought and behavior, as the asymmetries between different cultures and languages, did not occur smoothly, even in seemingly similar contexts (Smith, 2005).

One of the exponents of this movement, Durganand Sinha $(1997,1998)$, studied the process of indigenization of psychology in India and showed that the incorporation of Western psychological knowledge occurred within a general process of modernization of the country. His research showed that those who transferred knowledge tended to behave totally disconnected from local traditions, but those who received the psi knowledge often interpreted it within a framework of local reference. That is, what was peripheral was also central and the learned concept could be "culturally appropriate" (Sinha, 1997, p. 131).

The appropriation of concepts and categories of psychology, as well as their tools and methodologies, were historically mediated by social demands and cultural aspects through processes that did not happen homogeneously in different places. Besides India, studies were performed in countries as diverse as the Philippines - where there is an articulated analysis of indigenization of psychological 
knowledge to adapt concepts to make them more sensitive to Filipinos contextual factors (Church \& Katigbak, 2002) - Mexico, China, Cuba, Venezuela, Pakistan, Turkey and Canada (Adair, 1999; Sinha, 1997).

Although most of these indigenization investigations aim the formation of a native psychology, autonomous and autochthonous - which is beyond the scope of this article - they also contribute, in the historiographical point of view, to clarify the tensions and local disputes that occur within the transposition processes of the scientific psychology techniques and concepts. Therefore, they provide an interesting background to the psi knowledge insertion analysis in Brazil because the deployment of psychological procedures also produced displacement, resistance and several clashes in the country.

\section{Objective and methodology used in the research}

At a time to elucidate the formal aspects of the objective and methodology, it should also be clear the assumptions of this investigation, indicating the points on which it differs from resembled researchers. Mainly because there are approaches in the history of psychology that allude to notions such as "transfer" and "transmission" from the implicit view that the ideal role of indigenous scholars would be restricted to the accurate reproduction of knowledge received. That is, in these other studies what is questioned is the supposed integrity of psychological ideas transmitted and being considered successful the process in which there is a faithful reproduction of the theories taken as originals. Books, articles and texts written from this perspective tend to even establish a doubtful value judgment upon want to check how faithfully the new psi knowledge were transferred from their original environment, or observe the accuracy of local scholars, or enumerate any misconceptions that have come to dominate media receivers.

The article presented here, however, did not incorporate this essentialized interpretation of "center" and "periphery", because it advocates for critical review of the reified images that tradition- ally form the study of scientific activity in contexts considered peripheral (Gavroglu et al., 2008). What is sought in this research was to indicate the importance of the receptors and their varied responses to the analysis of what was being received.

Thus, the focus of this article refers to the appropriation process of psi knowledge in industrial education in Brazil, and more precisely to the application of psychological testing at the "Escola Técnica Nacional" (National Technical School), established by the Government Vargas in Rio de Janeiro in 1942. The idea was to show the specifics of this industrial education project, noting that at that time the policy interventions played a decisive role and shaped the processes of appropriation.

The research was based on the primary sources of the CEFET/RJ collection, whose Documentation Section/General Archives Sector is located in block $\mathrm{L}$ of the headquarters unit (Campus Maracanã), and has about two million five hundred thousand documents of students and nine hundred thousand historical and administrative documents (Silveira, 2009). The examination of these sources favored the 1942-1959 period and aimed the text and its historical context, since the intention was to highlight the dialogic relationship between documents about the tests applied - letters, reports, rules, written guidelines, manuals, answers table - and the discursive practices of the government of Vargas about industrial development.

The discussion of the results of this research is presented below from the perspective of questioning the notions of center and periphery. The historical analysis will show that like other processes of indigenization - in India, for example, there was growing skepticism about the psychological tests that were used indiscriminately without regard to its inadequacy to the Indian context (Sinha, 1998) — also at "Escola Técnica Nacional" mental tests faced resistance.

\section{The historical development of psychological testing}

The history of psi knowledge shows how psychology was gradually incorporating a variety of political 
projects for the individual control. In this context, at the dawn of the twentieth century, there was a methodological turn whereas the practice of investigative experiment was being replaced by test practical classification, marked by the relationship between a given score and a given individual (Rose, 2008).

Social institutions, such as schools and industries, particularly, constitute spaces where individuals could be observed, controlled, and tested for productive efficiency. Thus, under the aegis of objectivity, psychological testing was designed to transform individual differences in numbers, and human mind into something calculable and manageable. After its effective implementation, the test result - once ranked by the scale or the corresponding table - enabled the layout, stabilization, fixation, and the normalization of the social group.

This historical process cannot, however, be contemplated as if supposedly follow the direction of a straight line, a cumulative logic sequential events that were coming together and completing. Historical episodes, with no necessary relationship to each other, constitute a source that needs to be indicated, though.

In 1890, James McKeen Cattell published "Mental Tests and Measurements", where text was used perhaps for the first time, the term "mental test" in the psychological literature. In this article, Cattell described the tests he developed, methods for its implementation and the results obtained in a study with college students (Castro, Castro, Josephson, \& Jaco-Vilela, 2006). Hugo Münsterberg studies, however, prognosticated the relationship between psychological assessment and a more incisive industrial qualification. Many people even believe that Münsterberg marks the beginning of the so-called Industrial Psychology; either by publication in 1913 of Psychology and Industrial Efficiency (whose German version contains some differences), as the experiences in the use of psychological testing for the selection of workers railway lines, during the years 1903-1916, in the U.S. (Baptista, Rueda, Castro, Gomes, \& Silva, 2011).

In this classic work, Münsterberg (1913), which like Cattell studied under Wundt in Leipzig, cited explicitly Frederick Winslow Taylor (author of "The Principles of Scientific Management") and advocated the need to define tasks with reference to mental qualities desirable, as well as finding methods by which these mental qualities could be tested. The disclosure of "Psychology and Industrial Efficiency" developed concomitantly with other initiatives, especially the review that Stanford University had been doing from tests originally proposed by Binet in France. In fact, the expanded psychotechnical perspective of this period was the aspect that has led to some historians to coin the term "intelligence testing movement" (Zenderland, 1998), to describe a current of thought aligned with Taylorism-Fordism predominant in the United States at that time, with applications of testing intelligence focused on the military (army alpha and army beta tests) and the industrial context.

Parallel to the intelligence test, however, many aptitude tests were also being developed for use in industry, mainly in personnel selection. The Stenquist mechanical aptitude tests, the examination for office staff, and the Thurstone Minnesota paper form board test, created respectively in 1921, 1922 and 1928 are examples of this trend. The idea behind the application of all these tests is that they could be useful in the classification of certain people as more suitable for given functions, providing a better adaptation of the worker to his/her job (Castro et al., 2006).

Indeed, more than Europe (Smith, 2005), the psychology of the United States was what stimulated over the twentieth century, the massive use of psychological tests, giving them ample prestige in the society, including marked effects for producing a psychological culture of measurement. It is still worth mentioning, however, that the introduction of technical tests in Brazil was not so unequivocal, having the United States as a hegemonic central pole. And it even did not occur from a linear and direct relationship with any country seen as centers of knowledge, as those who defend the supposed primacy of conceptions static approach, in fact quite common in historical reviews on the psychology of work: "The road was only one way" (Silva \& Merlo, 2007, p. 135). 
What the Brazilian situation research allows to find, in contrast, is a great diversity of procedures performed by different people, in different places, which sometimes referred to research from their peers, and sometimes did not have the slightest knowledge of similar work. Thus, such dispersed confluences that make up the ownership of mental tests in Brazil do not allow any unidirectional interpretation in which such knowledge was gradually increasing and accumulating in a knowledge incrementally and continuously developed. What occurred were advances, duplications and reversals.

\section{The appropriation of psychological tests in Brazil}

In the cultural environment of Brazil, the discussion of psychological testing has received important contributions in the early twentieth century, as many were doing studies on this type of measurement applied to education and work, from the mid 1920s. Thus, the psychological technique became known through books like those of José Joaquim de Medeiros e Albuquerque ("Tests", 1924), Manoel Bonfim ("Method of Testing", 1928), Lourenço Filho ("Tests", 1931), and especially of Isaiah Alves — who had studied in the U.S. with Thorndike Edward Lee, a former student of Cattell — author of six testing studies within the period between 1927 and 1933. The main urban centers in Brazil — Rio de Janeiro, São Paulo, Minas Gerais, also Pernambuco and Bahia - were the most influenced ones by this trend that in Brazilian lands became also referred to as "movement of tests", and the expression, even the title of a book published by C.A. Baker, by Official Press of Minas Gerais in 1925 (Monarcha, 2001; Walger, 2006). This scenario, finally allowed to psychology a definite insertion in schools, especially in the current so-called "Escola Nova" (New School). Moreover, the New School Movement (in which Lourenço Filho was a reference) promoted principles such as free and compulsory public education, emphasizing the state's responsibility facing education (Ciavatta, 2009), but did not represent major influences in the design of industrial education in the 1940s, as the technical and vocational improvement itself.
Therefore, with regard specifically to the world of work, it is worth mentioning that the first incipient initiatives of applied psychology took place in São Paulo, in the main industrial center of the country. The Swiss engineer Roberto Mange, who had been invited to come to Brazil to teach Mechanics Applied to Machines at the "Escola Politécnica de São Paulo" (Abade, 2005; Antunes, 2001), is considered the precursor of testing during personnel selection because he used career aptitude tests developed by Fritz Giese (one of the pioneers of applied psychology in Germany) in 1925 in order to select students for the Practical Mechanics Course at the "Liceu de Artes e Ofícios of São Paulo".

The career of Roberto Mange (Araújo, 2013; Zanatta, 1991) is emblematic and helps deconstruct any linear arrangement structured to show a unilateral passive transposition of psychological techniques from the center to the periphery. $\mathrm{He}$ learned Portuguese as a child (as his father had business in Lisbon), studied in Germany, graduated in Zurich, worked in Belgium, came to Brazil in 1913, returned to Switzerland in 1914 (to report to the Army because of war), went back to São Paulo in 1915. He participated of studies on mental hygiene and hygiene applied to work (performed in Section Paulista of Mental Hygiene) with Lourenço Filho, directed the Practical Mechanics Course attached to the "Liceu de Artes e Ofício of São Paulo", traveled to Europe in 1923 in order to update. Then, he began the activities of the Vocational School in Mechanics School of "Liceu de Artes e Ofício of São Paulo", in 1924, returned to Germany in 1929 with the purpose of studying the working learning methods in railroads, and organized in 1930 the Office of Professional Education and Selection of Sorocabana Railroad; finally, in 1931, along with Lourenço Filho and others, he organized the Instituto de Organização Racional do Trabalho (IDORT Institute of Rational Organization of Labor).

In fact, the comings and goings of this process of appropriation of psychological knowledge are evident in Brazil and cut across individual pathways, as well as political groups and institutions. The attempt to generalize this experience in São Paulo to the whole country was endorsed years later 
mainly by the Ministry of Labor. However, due to the conflict between the guidelines and the Ministry of Labor and Ministry of Education in the late 1930s and early 1940s, the goal was not achieved and the performance of Mange remained more linked to the "Serviço Nacional da Aprendizagem Industrial" (Senai - National Service of Industrial Learning), in charge of the training of apprentices and connected to the National Federation of Industries (Schwartzman, Bomeny, \& Costa, 1984).

\section{Development of the industrial education in Brazil during Vargas Era}

Industry took some time to develop in Brazil because the colonial dynamic, which consisted exclusively on large-scale production of farm products for foreign trade, was perpetuated in the nineteenth century - through monoculture, landlordism and slavery - and early twentieth century. Because of this economic scenario, industrial education emerged in Brazil too different from what occurred in Europe and the United States (Cunha, 2000). The main difference was that as a consequence of past slave relations of production, free workers tried not to get involved with handicrafts, interpreted as menial labor activities. Therefore, initially, the teaching of crafts served as a welfare function and was intended to help children orphaned, abandoned or destitute, on a horizon where the few existing plants were very small, with a profile associated with manufacturing than industries (Iglésias, 1985).

The point is that in 1930 a revolution took place in Brazil, which is often interpreted as a result of the economic problems of the coffee export sector, victimized by the consequences of breaking the New York Stock Exchange in 1929 (Faust, 1997). In this context some sectors deprecated in previous governments for not belonging to the schemes pact to the agrarian elite, led Getulio Vargas to the presidency.

This episode is important because the Vargas government was essential to the effective industrialization of the country. The deadlines for the period in which he held the presidency of Brazil are often relaxed as his government tried from 1930 to 1945 interim government, constitutional and dictatorial, and even a return of the democratic vote in 1951. Thus, the general reference to the "Vargas Era" is very common in the historiography of the period.

The contingency that promoted the development of industrial education stems from trends that were mutually reinforcing. Several political groups claimed industrialization and the opinion in this regard was also shared by the urban middle classes, since they interpreted it as a sign of progress. However, besides the relationship between social progress and industrial development, there was another issue that was later imposed: the effects of war.

During World War II, Brazil (as well as other Latin American countries, especially Argentina and Mexico) was gradually industrializing because it needed to replace the local products and goods for those that were imported from Europe. The situation was very favorable because during the war there was an opportunity to create surpluses in the balance of payments, with consequent capital accumulation for investment in industry (Williamson, 2012).

One of the first actions of the provisional government of Vargas, still in 1930, was the creation of the Ministry of Education and Public Health. The following year, 1931, under the direction of Francisco Montojos, the "Inspetoria do Ensino Profissional Técnico" was created, which became "Superintendência do Ensino Industrial" (Superintendency of Industrial Education) in 1934. One of the main projects of the newly established Ministry of Education was the creation of a national system of industrial education from the implementation of a model school in Rio de Janeiro, the capital at the time. Thus, in 1935, Capanema Minister forwarded to Getúlio Vargas a document that suggested hiring 30 foreign teachers in order to prepare Brazilian teachers for the industrial education (Schwartzman et al., 1984).

The relevance of this political configuration, for the scope of this article, is that when conducting this broad reformulation of vocational and technical-industrial (Dias, 1980), psychological tests turn to be of special relevance in the selection 
and enrollment of students in technical courses just because at the same time, it was hegemonic the conception which attributed to the psychometric knowledge the condition to scientifically assess the skills of workers, within the political-administrative measures that sought to optimize the production process.

This background allows us to understand the decision of the Government to accept the Capanema plan and restructure the professional education in 1937 (Brandão, 2009; Fonseca 1961). The concern, which initially focused on educating the poor so they had a profession, began to be directed towards the need of using them for the industry of those who actually were more apt. This decision led to the creation of the "Escola Técnica Nacional" (National Technical School), which began its operations in July 15, 1942, with industrial level courses (very basic, focused on architects) and technical level (more refined and complex), some examples are: "Machinery and Engines Construction", "Electrotechnology", "Buildings construction" and "Technical Drawing".

This era, therefore, was marked by a break with what existed so far. Brazil in the 1930s and 1940s, in relation to industrial education, due to political and ideological elements, had totally different things at stake: either welfare or technical preparation for laying the needs and demands of industrialization (Ciavatta, 2009). Thus it is essential to note that the mandatory psychological evaluation was just the splitter element that distinguished a conception of industrial education from another one. In other words, it was a scientific psychological technique that legitimized the new industrial education.

\section{Analysis of documentation relating to the Escola Técnica Nacional mental test}

One of the most striking features of the National Technical School - standard industrial education school - is that the entrance exams include compulsory mental test, which have exclusionary effect. So with the redesign of technical education in the 1940s, a broader, comprehensive and institutionalized scenario was included than the isolated action of Roberto Mange in the Liceu de Artes e Ofícios of São Paulo, in the 1920s (Van Kolck, 1990).

Celso Suckow da Fonseca, director of the National Technical School (in the period between 1943 and 1951), celebrated these new era stating that

\footnotetext{
"it would not be only orphans, the poor, the unfortunate that schools would seek for their students. With the implementation of psychotechnology, the most capable would be enrolled, the ones who presented the best efficiency ratios, those who best reveal specific aptitudes for learning the craft and its subsequent use in the factories work". (Fonseca, 1961, p. 658)
}

What the document analysis showed is that such mental tests were developed by the Ministry of Education and were sent annually not only to the National Technical School, but to other technical schools across the country (as primary sources of the CEFET/RJ archive). It consisted of three stages - both the Industrial Course (Forms, Mechanics Knowledge and Similarities), and the Technical Course (Forms, and General Information and Number series) — and needed to be done in a period of 55 and 65 minutes, respectively.

However, the research carried out on existing documentation also showed that the procedures were improvised and superficial. The director of the Superintendence of Industrial Education, Francisco Montojos, referred to the school some guidance on the application and evaluation of the test. But sometimes the test questions were set aside for error printing on paper application, the fact that, by the standards of psychometrics would compromise the entire assessment. Another obstacle is that the $\mathrm{Na}$ tional Technical School had the task of assigning teachers the responsibility of applying and setting these mental level tests, a circumstance which also brought problems because they were not really qualified to do so.

It is possible to identify such inconsistencies in documents, such as the one found in box 62.5.1, classified as the period of the Escola Técnica $\mathrm{Na}$ cional (ETN fund). This is a non-signed report on to the process of selection of students for the year 
1945. The text under the heading "Report of the National Technical School" shows a number of inconsistencies that occurred in this context, where supposedly aptitude tests administered to students suited to Work Psychology for Taylorism at the time:

\begin{abstract}
"The tests of mental skill were not also eliminatory since there is not still the statistical basis of enough observations for safe conclusions in order to eliminate candidates. In previous years, it was observed that certain elements disposed on tests of mental ability, could in the following year overcome these tests and impose themselves as excellent students, even placing oneself in the first of its class".
\end{abstract}

This collected data allows to realize that if the formal point of view of the system prescribed was imposed as the scientific and psychometric, what actually took place was a practice guided by common sense which looked with marked distrust the criteria of psychology. Students eliminated due to the tests were effectively accepted, and aptitude tests were questioned concerning its liability.

Such inconsistency caused disruptions and at the end of the 1950s there was a radical change in the structure of industrial education and professional technical at National Technical School (Dias, 1980). The Ordinance 47.038 of October 16, 1959 resulted in the exclusive formation of technicians. The basic industrial courses that trained craftsmen were suspended, and the student admission process to technical course was restructured. Due to this amount of changes, admission exams conducted since 1960 no longer rely on the mental level test.

An analysis of this framework helps us infer that, once inserted into a specific local situation, the technique of psychological testing accomplished at the beginning of the industrial education of Brazil, a distinct function from those found in Europe or in the United States. At the National Technical School the mental test was defective in the classification of individual skills, but was relevant in relation to the legitimacy of the political and ideological project implemented by the government.

\section{Final considerations}

Aiming to analyze how the mental test was implemented in the National Technical School in the period between 1942 and 1959, this research was based on the method of document analysis to find that, from the perspective of traditional studies on transfer of knowledge between center and periphery, the appropriation of the technique was a huge failure. Tests were produced using common sense; they were applied without proper standardization and inadequately at the time of selecting the supposedly most suitable ones. Finally, they were abolished without any record of continuity and consolidation of knowledge acquired. As some may wish, the dissemination and use of psychological tests were decisive processes for the construction of psychology in Brazil (Baptista et al., 2011), however, the contribution from the National Technical School was null. Moreover, such considerations might even emphasize the irrelevance of this study for the sake of more productive investigations: After all, why should someone study an experiment that did not work?

However, the application of tests in the scope of the industrial education reform helps to expose some of the elements that are forgotten in more triumphalist prospects, because who receives a given implemented psychological technique is not a mere passive recipient having autonomy even to reject it. Within this logic, the greater relevance of this study is precisely to highlight the situation and frame of reference in which the technique was appropriate. The study shows that different initiatives, marked by an epistemological framework multifaceted of influences and dispersions were gradually overlapping, so that at the turn of the 1930s and early 1940s there was a trend in favor of the psychological assessment of individual skills.

These factors explain why the movement of tests on Brazilian soil. However, according to a more critical view, the key is to emphasize that during the industrial education reform from the government of Vargas - mental tests fulfilled a different purpose from that performed in their places of origin. In fact, in developed countries with 
strong and productive manufacturing tests aimed at classifying individuals according to their job skills. But in Brazil, where the amount of psychometric professionals capable to apply those tests was very small and the industry was just starting, tests exercised a function primarily ideological, once they provided an appearance of modernity to scientific and governmental projects. That is, like the lacquer used to improve the surface finish of the facade. So that, in a context where it would presumably opt for the discontinuity, tests remained for 18 years, and were applied and corrected even without any apparent validity, since their results were discarded.

With such maintenance procedure of tests, however, the National Technical School met the requests of the Board of Industrial Education. And the Ministry of Education continue announcing that the qualification had scientific basis since Vargas revolution - as befits all revolutions - had broken with the past and the delay of a school-based industrial welfare.

As the bibliographic survey allows to infer, Vargas era was marked by a nationalist economic policy in the interests of the industrial bourgeoisie, but also by the appreciation of the labor and the worker. In this scenario, the technicist solution towards the social problems aimed to legitimize the action of an authoritarian state, hence the recurrent praise to techniques: sometimes to scientific guise of statistics that estimated the minimum wage, sometimes to legal systematization of labor laws, sometimes to rationalization of public service, sometimes as this analysis noted, towards the use of mental test to select suitable students for a new project of industrial education.

To adequately involve the socio-ideological function of these technicists devices in Vargas era is fundamental to allude to a fruitful and contemporary category of growing urbanization and industrialization: the notion of populism (Ciavatta, 2009). Despite the profound influence of the United States, the political debate was dominated by a nationalist emphasis, with a more populist approach, characterized by the pursuit of popularity with the masses through processes of benefits and concessions than the consistency and density of the announced reforms.
Therefore, Brazilian history witnessed advances and setbacks. After the 1930 revolution, a civil war in 1932, a constitution promulgated in 1934, a communist uprising in 1935, a new coup in 1937, a declaration of war in 1942. Mental test was, then, one of the answers to the technicist legitimacy crisis, setting as neutral and scientific technical the open door to modernity.

\section{References}

Abade, F. L. (2005). Orientação profissional no Brasil: uma revisão histórica da produção científica. Revista Brasileira de Orientação Professional, 6(1), 15-24.

Adair, J. G. (1999). Indigenisation of Psychology: The concept and its practical implementation. Applied Psychology: An International Review, 48(4), 403-418.

Antunes, M. A. M. (2001). MANGE, Roberto (18851955). In R. H. de F. Campos (Ed.), Dicionário biográfico da psicologia no Brasil: Pioneiros (pp. 227 228). Rio de Janeiro: Imago.

Araújo, R. O. (2013). Classe dos gestores, corporativismo e psicotécnica: a trajetória de Roberto Mange através do Instituto de Organização Racional do Trabalho (1931-1942). (Unpublished doctoral dissertation). Universidade Federal de Goiás, Goiânia, Brasil.

Baptista, M. N., Rueda, F. J. M., Castro, N. R., Gomes, J. O., \& Silva, M. A. (2011). Análise de artigos sobre avaliação psicológica no contexto do trabalho: revisão sistemática. Psicologia em Pesquisa, 5, 156-167.

Brandão, M. (2009). CEFET Celso Suckow e algumas transformações históricas na formação profissional. Trabalho Necessário, 7(9), 20-40.

Castro, A. C., Castro, A. G., Josephson, S. C., \& JacoVilela, A. M. (2006). Medir, classificar e diferenciar. In A. M. Jacó-Vilela, A. F. Leal \& F. T. Portugal (Eds.), História da Psicologia: Rumos e Percursos (pp. 265-290). Rio de Janeiro: Nau editora.

Ciavatta, M. (2009). Mediações históricas de trabalho e educação. Rio de Janeiro: Lamparina/Faperj.

Church, A. T., \& Katigbak, M. S. (2002). Indigenization of psychology in the Philippines. International Journal of Psychology, 37(3), 129-148. 
Cunha, L. A. (2000). O ensino de ofícios nos primórdios da industrialização. São Paulo: UNESP.

Dias, D. O. (1980). Estudo documentário e histórico sobre a Escola Técnica Federal Celso Suckow da Fonseca. Rio de Janeiro: CEFET-RJ.

Fausto, B. (1997). A Revolução de 1930: historiografia e história. São Paulo: Companhia das Letras.

Fonseca, C. S. (1961). História do ensino industrial no Brasil. Rio de Janeiro: Escola Técnica Nacional.

Gavroglu, K., Patiniotis, M., Papanelopoulou, F., Simões, A., Carneiro, A., Diogo, M. P., Sánchez, J. R., \& Nieto-Galán, A. (2008). Science and technology in the European periphery: Some historiographical reflections. History of Science, 46, 153-175.

Iglésias, F. (1985). A industrialização brasileira. São Paulo: Brasiliense.

Monarcha, C. (2001). Lourenço Filho e a organização da psicologia aplicada à educação (São Paulo: 19211934). Brasília: Inep-Mec.

Munsterberg, H. (1913). Psychology and industrial efficiency. Boston/New York: Houghton Mifflin Company.

Rose, N. (2008). Psicologia como uma ciência social. Psicologia $\mathbb{E}$ Sociedade, 20(2), 155-164.

Schwartzman, S., Bomeny, H. M. B., \& Costa, V. M. R. (1984). Tempos de Capanema. São Paulo: EDUSP/ Paz e Terra.

Silva, P. C., \& Merlo, A. R. C. (2007). Prazer e sofrimento de psicólogos no trabalho em empresas privadas. Psicologia: Ciência e Profissão, 27(1), 132-147.
Silveira, Z. S. (2009). Algumas iniciativas em torno do resgate e preservação da memória do CEFET Celso Suckow da Fonseca. Trabalho Necessário, 7(9), 1-32. Sinha, D. (1997). Indigenizing psychology. In J. W. Berry, Y. Poortinga \& J. Pandey (Eds.), Handbook of crosscultural psychology. Theory and method (Vol. 1, pp. 129-169). Boston: Allyn \& Bacon.

Sinha, D. (1998). Changing perspectives in social psychology in India: A journey towards indigenization. Asian Journal of Social Psychology, 1, 17-31.

Smith, P. B. (2005). Is there an indigenous European social psychology? International Journal of Psycho$\log y, 40(4), 254-262$.

Van Kolck. O. L. (1990). Visão histórica da psicologia em São Paulo. Arquivos Brasileiros de Psicologia, 42(1), 155-160.

Walger, A. A. R. (2006). Psicometria e educação: A obra de Isaías Alves. (Unpublished doctoral dissertation). Pontifícia Universidade Católica de São Paulo, Brasil.

Williamson, E. (2012). História da América Latina. Lisboa: Edições 70 .

Zanatta, M. (1991). De homens e máquinas: Roberto Mange e a formação profissional. São Paulo: SENAI.

Zenderland, L. (1998). Measuring minds: Henry Herbert Goddard and the origins of American intelligence testing. Cambridge: Cambridge University Press. 